\title{
PERSEPSI MAHASISWA TERHADAP KUALITAS WEBSITE GEOPARK : KASUS PADA GEOPARK BATUR
}

\author{
Ayu Krishna Yuliawati ${ }^{1}$, Arief Budiman ${ }^{2}$,Shandra Rama Panji Wulung ${ }^{3}$, Asti Nur Aryanti ${ }^{4}$ \\ ${ }^{1}$ Program Studi Manajemen, Fakultas Pendidikan Ekonomi dan Bisnis, Universitas Pendidikan Indonesia, ${ }^{2}$ Program \\ Studi Kewirausahaan, Kampus Tasikmalaya, Universitas Pendidikan Indonesia, ${ }^{3}$ Program Pendidikan Pariwisata, \\ Fakultas Pendidikan Ilmu Pengetahuan Sosial, Universitas Pendidikan Indonesia, ${ }^{4}$ Program Studi Manajemen, STIE \\ INABA, Bandung, Indonesia \\ ayukrishna@upi.edu ${ }^{1}$,ariefbudiman@upi.edu²,wulung@upi.edu ${ }^{3}$, astinuraryanti@gmail.com ${ }^{4}$
}

\begin{abstract}
Geopark Global Geopark Batur as a geopark is not as well known as other geoparks in the world. Promotional efforts are carried out using the geopark website. The purpose of this study is to obtain the perception of students on Batur Global Geopark's website quality. The research method used is qualitative and respondents are students at UPI management study program. The results shows Batur Global Geopark website quality is quite good according to the respondents and able to attract several new customer and increase knowledge about geopark as a tourism destination.
\end{abstract}

Keywords: introduction to students; website quality; geopark; batur

\begin{abstract}
Abstrak
Geopark Batur sebagai geopark belum terkenal seperti geopark lainnya di dunia. Upaya promosi yang dilakukan melalui situs internet. Tujuan penelitian ini adalah untuk mengetahui persepsi mahasiswa terhadap kualitas website Global Geopark Batur. Metode penelitian yang digunakan adalah kualitatif. Responden penelitian adalah mahasiswa program studi manajemen UPI. Hasil penelitian menunjukan bahwa kualitas situs website geopark cukup baik menurut responden dan dapat menarik pelanggan baru dan meningkatkan pengetahuan tentang geopark sebagai tourism destination.
\end{abstract}

Kata Kunci: persepsi mahasiswa; kualitas website; geopark; batur

Corresponding author: Email : ayukrishna@upi.edu

History of article : Received : Juli 2018 , Revised : September 2018, Published : November 2018 


\section{PENDAHULUAN}

Berdasarkan data pemerintah Kabupaten Bangli, jumlah wisatawan yang berkunjung ke Kaldera Batur terus mengalami peningkatan. Pada 2012 jumlah pengunjung yang datang ke Kaldera Batur mencapai sekitar 500.000 orang, sedangkan tahun sebelumnya hanya sekitar 300.000 orang. Pada tahun 2015 jumlah pengunjung yang datang ke Kaldera Batur diharapkan mencapai 600.000, (www.voaindonesia.com). Namun jumlah ini masih dibawah jumlah pengunjung ke Geopark Malaysia yaitu 3.4 juta turis. Website membuat kesan pertama yang kuat untuk merek suatu geopark. Sangat penting bahwa pengelola situs Geopark Batur menyusun website yang dapat diakses, mudah digunakan, dan informatif. Kualitas website dapat mempengaruhi persepsi konsumen mengenai suatu Geopark.

Website yang interaktif dimana pengunjung website dapat mengupload foto, video dan review produk/jasa pariwisata akan memberikan dampak yang baik bagi pemasaran Geopark. Batur sebagai geopark kelas dunia dalam peningkatan konservasi, pendidikan, dan pemberdayaan masyarakat melakukan promosi melalui situs internet. Tujuan penelitian ini adalah untuk mengetahui persepsi mahasiswa terahdap kualitas website geopark Batur.

\section{KAJIAN PUSTAKA \\ Pengertian dan Konsep Website}

Internet telah mengubah tempat pertukaran dari marketplace (seperti, interaksi face-to-face) menjadi marketspace (seperti, interaksi screen-to-face). Perbedaan utama adalah bahwa sifat hubungan pertukaran sekarang ditengahi oleh interface teknologi. Dengan perpindahan dari hubungan antarmuka people-mediated menjadi technology-mediated, terdapat sejumlah pertimbangan perancangan interface yang dihadapi.
Menurut Rayport dan J.Jaworski. (2003), ada berbagai elemen dalam mendesain sebuah situs web, yaitu context (konteks dari situs mencerminkan nilai keindahan dan kegunaan dari situs tersebut), content (konten merupakan semua objek digital yang terdapat dalam sebuah web baik dalam bentuk audio, video, image ataupun text), community (komunitas merupakan ikatan hubungan yang terjadi antara sesama pengunjung atau pelanggan dari sebuah website karena adanya kesamaan minat atau hobi).

Selain itu terdapat customization (kustomisasi merupakan kemampuan situs untuk memodifikasi dirinya sesuai dengan keinginan penggunanya), communication (komunikasi antara perusahaan dengan pelanggan, terdiri dari Broadcast Dimension, Interactive Dimension, dan Hybrid Dimension), connection (kemampuan sebuah website untuk berpindah dari sebuah webpage ke webpage lainnya ataupun website lainnya dengan onclick baik pada text, images maupun toolbars yang lain), dan commerce (commerce merupakan fitur dari customer interface yang mendukung berbagai aspek dari transaksi perdagangan dan memiliki dimensi seperti registration, shopping cart, security, credit card approval, one click shopping, order through affiliates, configuration technology, order tracking, delivery option).

\section{Kualitas Website}

Peningkatan kunjungan pariwisata melalui website perlu disesuaikan dengan preferensi masyarakat. Artinya konten yang disajikan dalam sebuah website pariwisata mampu mewakili kebutuhan berwisata para pengunjung. Untuk itu pengelola pariwisata perlu memperhatikan kualitas website destinasi wisata dalam rangka promosi. Barnes dan Vidgen (2001) menyatakan bahwa kualitas dapat dikategorikan menjadi tiga, yaitu kualitas website, kualitas informasi, dan kualitas interaksi pelayanan. 
Kualitas sebuah website pariwisata dapat menjadi kunci peningkatan jumlah kunjungan. Pasalnya, wisatawan dapat menjadi tertarik ketika melihat tampilan website. Semakin tinggi kualitas website maka semakin banyak pula pelanggan yang akan merasa puas (Getty \& Getty, 2003).

Untuk meningkatkan jumlah wisatawan, manajemen pariwisata perlu menggunakan strategi pemasaran untuk kegiatan promosi yang efektif. Saat ini cara yang dinilai efektif adalah promosi melalui media online termasuk juga website. Promosi merupakan salah satu cara mengembangkan minat beli, yakni melalui komunikasi yang serta memperoleh respon (Lamb dalam Rizky dan Yasin, 2014).

\section{Promosi Geopark}

Geopark merupakan wilayah dengan warisan geologi tertentu yang memiliki signifikansi internasional, kelangkaan atau daya tarik estetika, yang dikembangkan sebagai bagian dari konsep terpadu konservasi, pendidikan dan pengembangan ekonomi lokal (UNESCO, Global Geoparks Network, 2006). Geopark sebagai warisan geologi memiliki dayatarik tersendiri bagi wisatawan. Tidak hanya meningkatkan sektor pariwisata dikawasan geopark berada, namun pariwisata geopark juga dapat meningkatkan ekonomi lokal serta terjaganya kondisi alam disekitarnya. Promosi dalam hal ini menjadi penting guna meningkatkan citra geopark sebagai destinasi wisata yang direkomendasikan.

Proses promosi geopark menjadi efektif dan menjangkau skala global adalah melalui penyajian penawaran destinasi melalui konten-konten di website. Dengan demikian, para wisatawan domestik dan mancanegara dapat dengan mudah mengakses informasi tentang destinasi geopark. Promosi geopark dengan memanfaatkan tampilan kualitas website, akan meningkatkan kepercayaan dan komitmen yang tercipta melalui elemen komunikasi dan teknologi.
Nilai ini yang selanjutnya dapat membangun nilai kepuasan jangka panjang bagi pengunjung geopark (Mukherjee dan Nath, 2007; Velmurugan, 2009; $\mathrm{Xu}$ et al, 2014). Kepuasan wisatawan atas kesesuaian konten website geopark dengan reality yang dirasakan ketika beriwisata di geoaprk tersebut, menjadi indicator penting dalam mengelola brand image. Diketahui bahwa mengembangkan dan mengelola merek sangat penting bagi karena merupakan salah satu aset paling berharga (Baalbaki \& Guzmán, 2016; Keller \& Lehman, 2006). Mengingat pentingnya sebuah merek geopark, diperlukan upaya yang signifikan untuk menganalisis berbagai faktor yang dapat meningkatkan merek, terutama dari perspektif wisatawan (Williams \& Soutar, 2009).

Salah satu strategi marketing yang dapat dilakukan oleh pengelola geopark adalah melihat potensi teknologi dalam menyebarkan informasi, sehingga dapat memberikan informasi lengkap mengenai fasilitas yang ditawarkan untuk menarik minat beli wisatawan. Manajemen geopark akan mendapatkan keuntungan jika mampu memasarkan geopark melalui website, yakni kecenderungan masyarakat saat ini adalah mempergunakan media online dalam mencari informasi apapun (termasuk destinasi wista), serta infomasi yang dimuat dalam sebuah media online (website) dapat diakses 24jam oleh wisatawan (Andoy dalam Fahmi dan Irawan, 2010).

\section{METODE PENELITIAN}

Penelitian ini menggunakan metode penelitian kualitatif, sehingga analisis deskriptif dilakukan dalam penelitian. Data yang digunakan dalam penelitian ini adalah data primer dan data sekunder. Data primer diperoleh melalui wawancara dan pengisian kuesioner dengan mahasiswa Program Studi Manajemen, Universitas Pendidikan Indonesia sebanyak 100 orang. Pengumpulan data dilakukan melalui studi pustaka, studi lapangan, observasi dan wawancara. 


\section{HASIL DAN PEMBAHASAN}

Berdasarkan data pada Tabel 1 diketahui bahwa responden dari kalangan mahasiswa $34 \%$ mengetahui situs website Batur Global Geopark, dan banyak yang tidak mengetahu adanya website geopark. Hal ini menunjukkan kurangnya promosi mengeai situs geopark yang dilakukan olen Badan Pengelola Geopark.

Tabel 1

Responden Mengetahui Adanya Situs Geopark

\begin{tabular}{|c|c|}
\hline Website geopark & Prosentase \\
\hline Batur & 34 \\
\hline Sewu & 10 \\
\hline Cilentuh & 7 \\
\hline Tidak ada & 42 \\
\hline Lainnya & 7 \\
\hline Jumlah & 100 \\
\hline
\end{tabular}

Berdasarkan data pada Tabel 2 yang memperlihatkan pengalaman responden berdasarkan berapa kali mengunjungi situs website Batur Global Geopark yang didominasi oleh jawaban yang menyatakan bahwa mayoritas responden sudah mengunjungi website sebanyak 1 kali atau bisa dikatakan bahwa itu merupakan mayoritas berusia diantara 19- 20 tahun mengunjungi situs website Batur Global Geopark yaitu sebesar $22 \%$.

Tabel 2

Frekuensi Responden Mengunjungi Situs Website Batur Global Geopark

\begin{tabular}{|l|c|c|c|c|c|}
\hline & \multicolumn{3}{|c|}{ Berapa_Kali } & \multirow{2}{*}{ Total } \\
\cline { 2 - 5 } & $\begin{array}{c}1 \\
\text { Kali }\end{array}$ & $\begin{array}{c}2- \\
\text { 3Kali }\end{array}$ & $\begin{array}{c}4-5 \\
\text { Kali }\end{array}$ & $\begin{array}{l}>5 \\
\text { Kali }\end{array}$ & \\
\hline $\begin{array}{l}\text { Frekuensi mengunjungi } \\
\text { situs Batur Global } \\
\text { Geopark }\end{array}$ & $68 \%$ & $29 \%$ & $1 \%$ & $2 \%$ & $100 \%$ \\
\hline
\end{tabular}

Berdasarkan data pada Tabel 3 yang memperlihatkan hubungan antara karakteristik responden berdasarkan usia dan sumber yang memberikan informasi mengenai situs website Batur Global Geopark, responden menyatakan bahwa social media merupakan sumber informasi.

Tabel 3. Sumber yang Memberi Informasi Mengenai Situs Website Batur Global Geopark

\begin{tabular}{|c|c|}
\hline Sumber Informasi & Prosentase \\
\hline Teman & 31 \\
\hline Keluarga & 2 \\
\hline Social Media & 56 \\
\hline Iklan & 8 \\
\hline Lainnya & 3 \\
\hline Total & 100 \\
\hline
\end{tabular}

Berdasarkan data pada Tabel 4 pertanyaan mengenai website pariwisata yang diketahui oleh responden, menyatakan bahwa situs website pariwisata yang mereka ketahui paling banyak adalah adalah situs Wonderful Indonesia sebesar $76 \%$.

Tabel 4. Website Pariwisata yang Diketahui

\begin{tabular}{|c|c|}
\hline Website Pariwisata & Prosentase \\
\hline Wonderful Indonesia & 76 \\
\hline Peucang Island & 2 \\
\hline Go Indonesia & 4 \\
\hline Tidak ada & 17 \\
\hline Lainnya & 1 \\
\hline Total & 100 \\
\hline
\end{tabular}

Berdasarkan data pada Tabel 5 yang tujuan mengunjungi website pariwisata, jawaban responden didominasi oleh jawaban bahwa pada mahasiswa menyatakan bahwa tujuan mereka mengunjungi website pariwisata adalah untuk mendapatkan referensi tempat wisata yaitu sebesar $27 \%$ atau sebanyak 27 orang responden.

Tabel 5

Tujuan Mengunjungi Website Pariwisata

\begin{tabular}{|c|c|}
\hline $\begin{array}{c}\text { Tujuan mengunjungi } \\
\text { website }\end{array}$ & Prosentase \\
\hline Mendapatkan referensi & 59 \\
\hline Menambah pengetahuan & 4 \\
\hline Mendapatkan informasi & 32 \\
\hline Lainnya & 5 \\
\hline Total & 100 \\
\hline
\end{tabular}


Hasil pengumpulan data mengenai dimensi context dalam website, mayoritas responden menyatakan kecenderunganya bahwa setuju layout situs Batur Global Geopark sangat mudah bagi user untuk mencari informasi yang diperlukan, yaitu sebanyak $42,8 \%$ atau sebanyak 9 orang responden dari total 21 orang responden menyatakan netral dan setuju, pada pernyataan kedua responden menyatakan setuju sebesar 47,6\% atau sebanyak 10 orang bahwa desain situs sangat menarik bagi merek asebagai user. Sedangkan pada pernyataan ketiga responden menyatakan setuju pada pernyataan memuat informasi sangat lengkap mengenai produk pariwisata Batur Global Geopark.

Hasil pengumpulan data mengenai dimensi content dalam website, $47,61 \%$ atau sebanyak 10 orang dari total 21 orang responden menyatakan setuju bahwa website Batur Global Geopark memuat informasi yang sangat lengkap mengenai pariwisata. Informasi lainnya adalah sebesar 47,61\%, responden setuju bahwa isi visual yang berupa foto, gambar, video yang berkaitan dengan destinasi pariwisata Batur Global Geopark yang ditampilkan mengenai pariwisata sangat menarik. Pada item pertanyaan ketiga $61,90 \%$ responden setuju bahwa informsi yang terdapat dalam situs website sangat bermanfaat. yaitu banyaknya responden yang setuju Untuk item pertanyaan keempat didominasi oleh alternatif jawaban setuju sebesar $66,67 \%$ menyatakan setuju bahwa informasi yang disajuikan dalam situs website sangat beragam.

Berdasarkan data pada keempat pernyataan mengenai dimensi content, responden memberikan tanggapan positif terhadap website yang memberikan informasi yang lengkap, bermanfaat dan sangat beragam mengenai pariwisata dan juga isi website yang berupa gambar, foto dan video sangat menarik.

Berdasarkan Gambar 1 mengenai persepsi responden tentang Community, kemudahan melakukan komunikasi interaktif antara pengguna situs dengan pengguna lainnya menunjukkan bahwa responden menyatakan cukup setuju atau ragu-ragu sebesar $47,62 \%$. Berdasarkan data pada gambar diatas mengenai Customization, menunjukkan bahwa pernyataan didominasi oleh alternatif jawaban cukup setuju atau ragu-ragu sebesar $66,67 \%$ atau sebanyak 14 orang dari total 21 orang responden, responden ragu-ragu bahwa sangat mudah bagi situs website untuk disesuaikan dengan kebutuhan dan preferensi pengguna.

Gambar 1

Persepsi Responden Tentang Community

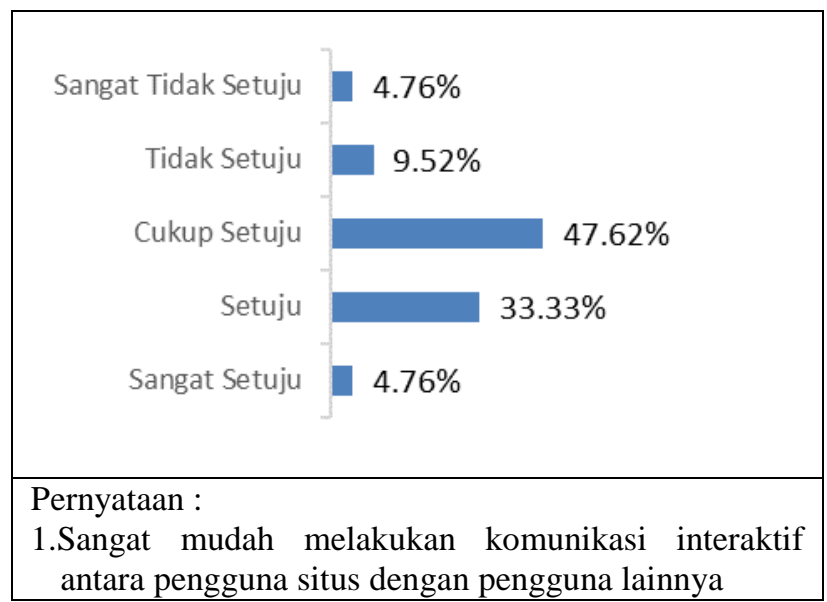

Berdasarkan data pada Gambar 2 diatas mengenai Customization, menunjukkan bahwa pernyataan didominasi oleh alternatif jawaban cukup setuju atau ragu-ragu sebesar $66,67 \%$ atau sebanyak 14 orang dari total 21 orang responden, responden ragu-ragu bahwa sangat mudah bagi situs website untuk disesuaikan dengan kebutuhan dan preferensi pengguna.

Berdasarkan data pada Gambar 2 diatas mengenai Customization, menunjukkan bahwa pernyataan didominasi oleh alternatif jawaban cukup setuju atau ragu-ragu sebesar $66,67 \%$ atau sebanyak 14 orang dari total 21 orang responden, responden ragu-ragu bahwa sangat mudah bagi situs website untuk disesuaikan dengan kebutuhan dan preferensi 
pengguna.

Gambar 2

Persepsi Responden terhadap Customization

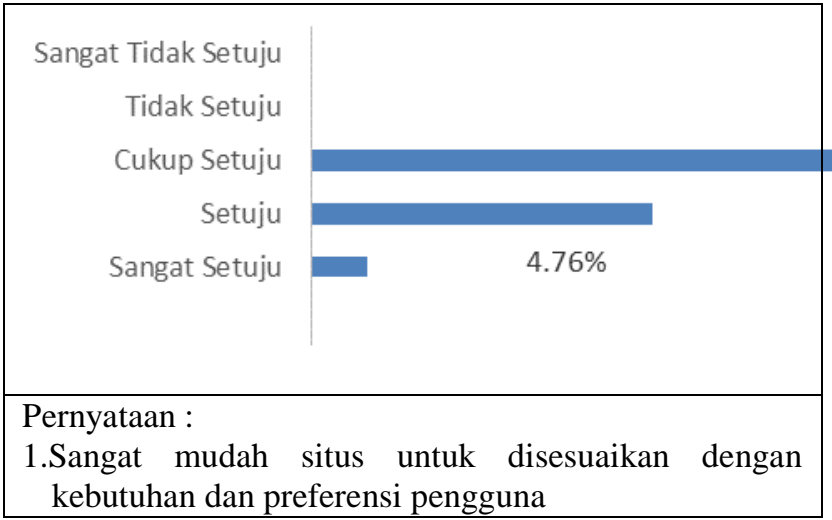

Berdasarkan data pada Gambar 3 diatas mengenai Communication, menunjukkan bahwa pernyataan pertama didominasi oleh alternatif pilihan jawaban setuju sebesar $42,86 \%$ atau sebanyak 9 orang dari total 21 orang responden, responden setuju bahwa sangat mudah bagi pengelola situs website melakukan komunikasi pada pengguna. Sedangkan pada pernyataan kedua pilihan jawaban didominasi oleh alternatif jawaban cukup setuju atau ragu-ragu sebesar $42,86 \%$ atau sebanyak 9 orang responden menyatakan ragu-ragu terhadap pernyataan bahwa sangat sering pengelola situs website berkomunikasi degan pengguna secara online

Gambar 3

Persepsi Responden terhadap Communication

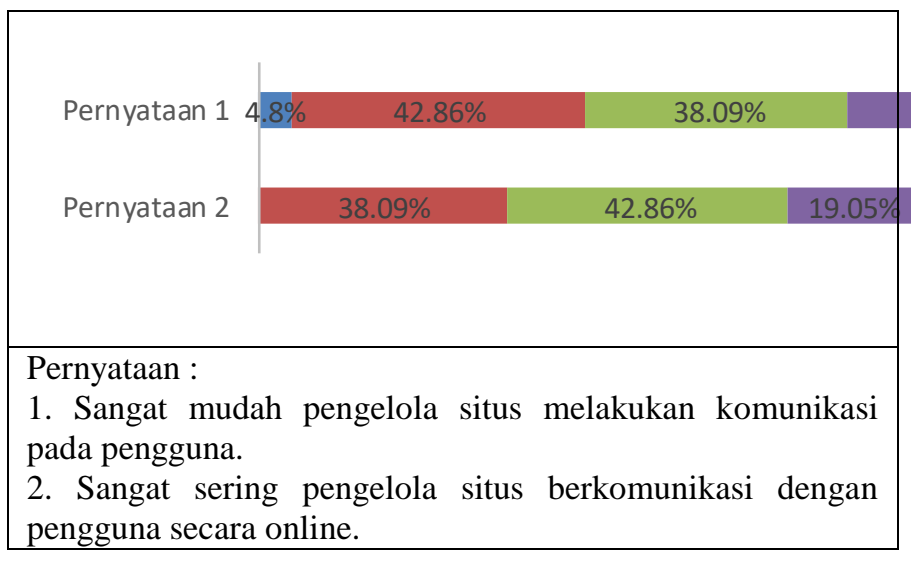

Pengelola geopark Batur melakukan promosi salah satunya dengan menggunakan website dimana hal ini sejalan dengan nelalui Kementerian Kemaritiman, lan Sumber Daya $28.57 \%$ 66.67\% in Pariwisata dimana pariwisata Indonesia an Geopark Network (GGN) 2016 yang

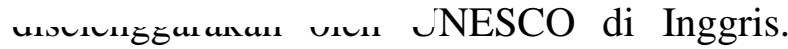
Promosi merupakan salahsatu bentuk komunikasi yang dilakukan oleh pihak pengelola kawasan.

Hal ini juga sejalan dengan sosialisasi Batur sebagai geopark kelas dunia dalam peningkatan konservasi, pendidikan, dan pemberdayaan masyarakat. Geopark Batur merupakan satu-satunya geopark yang secara resmi telah diakui oleh UNESCO. GGN UNESCO secara berkala senantiasa memantau dan mengevaluasi aktivitas geopark pariwisata Global Geopark Batur.

Model promosi Website geopark Batur yang dikelola oleh DMO berkinrja cukup baik. Model tersebut dianalisi berdasarkan 7c dari rayport dan Jaworski (2003). Sejalan dengan teori tersebut bahwa website goepark batur telah memenuhi syarat menjadi website yang informatif dan memilki daya bujuk pengunjung website untuk berkunjung ke destinasi geopark batur.

Program promosi yang dilakukan oleh DMO goepark batur telah cukup berhasil alam meningkatkan kesadaran merek. Hal ini ejalan dengan teori kesadaran merek yang ikemukakan oleh Keller (2013) bahwa esadaran merek yang bangun melalui rebsite dapat memberikan beberapa keuntungan. Pertama, keuntungan pembelajaran sebagai pembelajaran mempengaruhi pembentukan dan kekuatan asosiasi yang membentuk citra merek bagi konsumen. Kedua, keuntungan sebagai pertimbangan adalah ketika konsumen harus mempertimbangkan suatu merek setiap kali mereka membuat keputusan untuk 
pembelian yang dapat memenuhi kebutuhan tersebut dan dapat memuaskan.

Dengan kesadaran merek yang bagus memungkinkan menjadi bahan petimbangan konsumen dalam pembelian. Terakhir, Keuntungan sebagai pilihan adalah keuntungan untuk menciptakan kesadaran merek tingkat tinggi dimana hal tersebut dapat mempengaruhi pilihan antara merek yang dijadikan pertimbangan oleh konsumen, bahkan jika ada dasarnya tidak ada asosiasi merek lain yang dijadikan sebagai pertimbagnan bagi mereka, maka merek tersebut menjadi pilihan bagi konsumen.

Berdasarkan data pada Gambar 4 diatas mengenai Connection nmenunjukkan bahwa pernyataan mengenai dimensi connection didominasi oleh alternatif jawaban cukup setuju atau ragu ragu sebesar $57,14 \%$ atau sebanyak 12 orang dari total responden sebanyak 21 orang responden, responden merasa ragu-ragu bahwa situs website Batur Global Geopark memiliki keterhubungan tinggi dengan situs lain.

Gambar 4

Persespi Responden Mengenai Connection

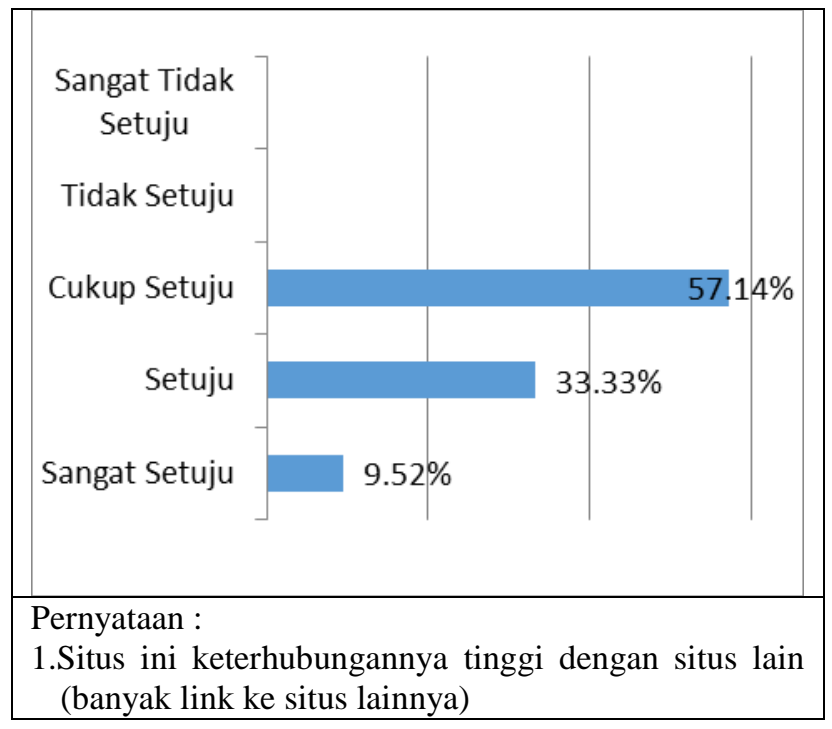

Berdasarkan pada Gambar 5 mengenai Commerce didominasi oleh alternatif jawaban cukup setuju atau ragu-ragu sebesar $57,14 \%$ atau sebanyak 9 orang dari total 21 orang responden. Responden menyatakan ragu-ragu bahwa website memiliki kemampuan yang sangat tinggi dalam menarik sponsorship/iklan.

Gambar 5

Persepsi Responden terhadap Commerce

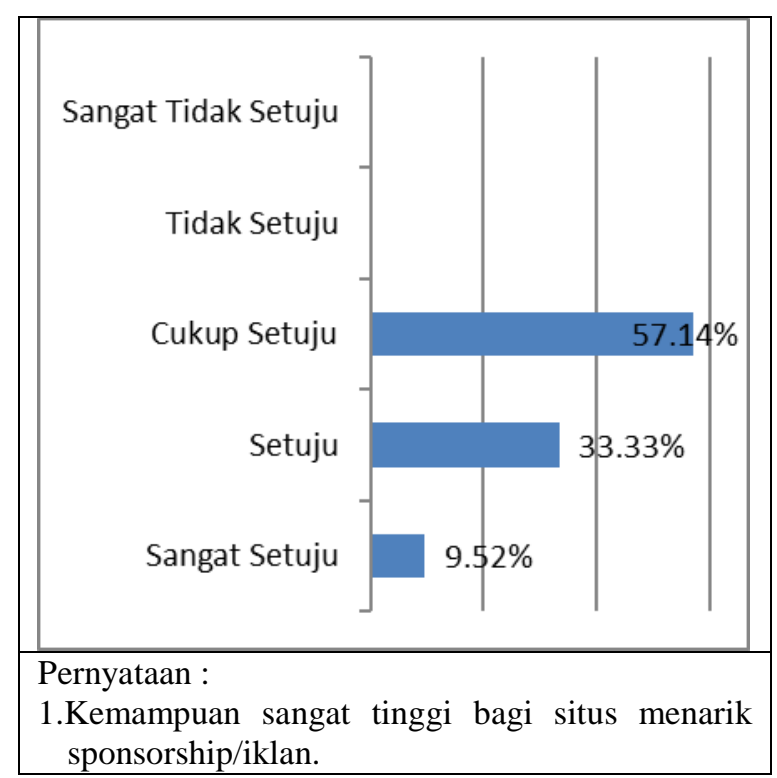

\section{KESIMPULAN DAN SARAN}

Peran teknologi komunikasi dinilai sangat strategis dalam bidang pariwisata. Situs web komunikasi memainkan peran penting dalam memberikan informasi situs pariwisata dan mempermudah pengambilan keputusan dalam memilih opsi perjalanan wisata. Mahasiswa terutama menjadi target strategis kualitas web pariwisata (terutama Geopark). Seperti diketahui bahwasanya generasi milenial adalah generasi yang paling peka terhadap teknologi informasi.

Situs website Batur Global menjadi efektif karena pengalaman pertama responden mengakses website geopark Batur Geopark cukup baik. Saat ini era dimana situs menjadi sarana informasi yang paling cepat menyebar, sehingga jika dikaitkan dengan kepentingan promosi Geopark, hal ini dirasa sangat efektif. Selain menginformasikan layanan wisata, situs website pariwisata juga dapat membantu pengambilan keputusan wisatawan dalam 
melakukan perjalanan pariwisata.

Dalam upaya untuk meningkatkan kualitas situs website, perlu adanya perbaikan dalam situs website geopark. Diantaraya adalah context website (terutama layout), content website (terutama keberagaman informasi yang disajikan), community (terutama kemudahan komunikasi interaktif di website), customize (terutama penyesuaian dengan preferensi user), communication (kemudahan pengelolaan situs terutama proses komunikasi dengan pengguna), connection (keterkaitan dengan situs lainnya), commerce (kemenarikan situs dalam menarik sponsorship/iklan).

\section{DAFTAR PUSTAKA}

Baalbaki, S. dan Guzmán, F. (2016). A consumer-perceived consumer-based brand equity scale. Journal of Brand Management, 23(3), 229-251.

Barnes, Stuart J. dan Vidgen, R. (2001). Assessing the Quality of Auction Websites. Proceeding of the 34th Hawaii International Conference on System Sciences.

Fahmi, Husni dan Irawan (2010). Pengukuran Kinerja Situs Web, Pusat Teknologi dan Komunikasi, Badan Pengkajian dan Penerapan Teknologi

Getty, J. M. dan Getty, R. L., (2003). Lodging quality index (LQI): Assessing customers' perceptions of. Quality Delivery. International Journal of Contemporary Hospitality Management, 15(2), 94-104.

Keller, Kevin Lane., dan Lehman, D. R. (2006). Brands and branding: Research findings and future priorities. Marketing Science, 25(6), 740-759.

Keller, Kevin Lane. (2008). Strategic and Brand Management: Building, Measuring, and Managing, Brand Equity. New Jersey: Prentice Hall Inc.

Mukherjee, A., dan Nath, P. (2007). Role of Electronic Trust in Online Retailing: A Examination of The Commitmenttrust theory. European Journal of Marketing,
41(9), 1173-1202.

Rayport, J. F. dam Jaworski, B. J. (2003). Introduction to E-Commerce Second Edition. Singapore: McGrawHill.

Rizky, M.F. dan Yasin, H. 2014. Pengaruh Promosi dan Harga Terhadap Minat Beli Perumahan Obama PT. Nailah Adi Kurnia. Jurnal Manajemen dan Bisnis. 14(2), 135-143.

UNESCO. Global Geoparks Network. 2006. Published by Division of Ecological and Earth Sciences. UNESCO Paris.

Velmurugan, M. S. (2009). Security and trust in e-Business: Problems and Prospects. International Journal of Electronic Business Management, 7(3), 151-158.

Williams, P., \& Soutar, G. N. (2009). Value, Satisfaction and Behavioral Intentions In An Adventure Tourism Context. Annals of Tourism Research, 36(3), 413-438

Xu, Jie. et.al. (2014). How Different Types of Users Develop Trust In Technology: A Qualitative Analysis Of The Antecedents of Active And Passive User Trust In A Shared Technology. Applied Ergonomics. 45(6), 1495-1503. 
Journal IMAGE | Volume 7, Number 2, November 2018, page 51-58 
Journal IMAGE | Volume 7, Number 2, November 2018, page 51-58 
Journal IMAGE | Volume 7, Number 2, November 2018, page 51-58 
Journal IMAGE | Volume 7, Number 2, November 2018, page 51-58 
Journal IMAGE | Volume 7, Number 2, November 2018, page 51-58 
Journal IMAGE | Volume 7, Number 2, November 2018, page 51-58 
Journal IMAGE | Volume 7, Number 2, November 2018, page 51-58 